\title{
MYTHOPOETICS OF THE IMAGE OF THE MAIN HERO IN S. LUNOV'S OPERA "MOSCOW-PETUSHKI"
}

\author{
Mariia Turchyna \\ Postgraduate Student, Ukrainian National Tchaikovsky Academy of Music, Ukraine \\ e-mail: marushka1513@gmail.com,orcid.org/0000-0003-2342-014X
}

\section{Summary}

The article analyzes the mythopoetics of the image of the main hero Venichka Yerofeyev in the opera "Moscow-Petushki" by the modern Ukrainian composer S. Lunov. The concept of "culture hero" and its explication on the image of Venichka Yerofeev are considered. The etymology of the concept of "culture hero", its meaning both in archaic mythological thinking and in modern society is studied. It was found that for each epoch there is a culture hero, who is the personification of the dominant cultural values in society. The functions of a culture hero in society, his positive and negative traits and qualities of activity are considered. Based on the latter, the trickster features inherent in the culture hero, which were inherent in the original mythological thinking, but are relevant in our time, are emphasized. The history of S. Lunov's creating of opera "Moscow-Petushki" is considered, the libretto of the opera and V. Yerofeyev's poem of the same name is compared from the standpoint of genre and compositional features. It has been found that the mythopoetic image of the protagonist of the opera embodies both the features of a cultural hero and a trickster, which refers us to the original mythology, when these images existed syncretically. It was found that the cultural hero Venichka Yerofeyev embodies the following features: creative transformation of reality, cultural and organizational, mediation, protective and didactic.

Key words: myth, culture hero, trickster, Venichka Yerofeyev, composition.

\section{DOI: https://doi.org/10.23856/4417}

\section{Introduction}

One of the features of the development of culture of the XX and early XXI century was the growing interest in mythology. In modern culture, the universal features of mythological thinking are constantly reproduced, mythical issues, themes, systems of images, etc. are reconsidered and find a new embodiment. Characters of archaic, mythological notions are becoming increasingly popular research topics in the humanities, in particular, culturology and art history. One of such characters is a culture hero who transforms the world from a state of primordial chaos, and through his active mediation new values are created, the universe is established and maintained. A culture hero qualitatively changes people's lives through his inventions or discoveries of new things, thanks to which society makes a leap in development.

Today there are many forms of realization of a culture hero in almost all areas: art, science, business, administration, education and more. The presence of a culture hero in the art of music was no exception, in particular, the opera "Moscow-Petushki" by the contemporary Ukrainian composer S. Lunov.

Analysis of recent research and publications. The image of a culture hero and its manifestations in mythology and culture have been studied in various branches of the humanities: philosophy, culturology, history, etc. Among the scientific developments and explorations 
there are works on the mythological essence of the cultural hero: K. Breysig (Breysig, 1905), P. Ehrenreich (Ehrenreich, 1905), A. Lang (Lang, 1901), Y. Meletinsky (Meletinsky, 1995), W. Schmidt (Schmidt, 1933), M. Eliade (Eliade, 2010), A. Pelipenko, I. Yakovenko (Pelipenko, Yakovenko, 1998), C. Lévi-Strauss (Lévi-Strauss, 2001), C. Jung (Jung, 1996), O. Hrytsenko (Hrytsenko, 1999), Yu. Bentia (Bentia, 2020) and others.

Numerous scientific investigations are devoted to the work of V. Yerofeyev, his poem "Moscow-Petushki", which explores intertextual connections and allusions to various cultural texts, which directly borrowed or indirectly relied on the author in his poem, also in the works of A. Genis (Genis, 1997), S. Lashchenko (Lashchenko, 2004), M. Lipovetsky (Lipovecky, 1997), and others. Musicological explorations by N. Vasina (Vasina, 2009), O. Mozar (Motsar, 2014) are devoted to the peculiarities of S. Lunov's compositional work and his opera "Moscow-Petushki", which was first analyzed in the context of the aesthetics of the absurd in the dissertation research of Ukrainian musicologist O. Motsar "Ideas of the theater of the absurd in the process of updating the musical theater of the last third of the XX - early XXI century" (Motsar, 2016). However, in the presented scientific investigations and publications devoted to this issue, the question of the mythopoetics of the image of the protagonist "Moscow-Petushki", which plays a fundamental role in the formation of the opera, remains unsolved.

The aim of the article is to explore the mythopoetics of the image of Venichka Yerofeyev in the context of the features of a culture hero in S. Lunov's opera "Moscow-Petushki".

This goal necessitated the solution of the following tasks:

1. to reveal the mythological essence of a culture hero;

2. to analyze the common and distinctive features of V. Yerofeyev's poem and S. Lunov's opera "Moscow-Petushki";

3. to analyze the mythopoetic features of the culture hero in the image of Venichka Yerofeyev in S. Lunov's opera "Moscow-Petushki".

The methodology is based on a systematic approach, historical and comparative, cultural and anthropological, logical and analytical methods, as well as scientific culturological, philosophical, literary and musicological explorations.

The scientific novelty of this article is due to the fact that for the first time the mythopoetics of the image of the main character Venichka Yerofeyev became the subject of a special musical and cultural study of S. Lunov's opera "Moscow-Petushki".

\section{Characteristics of a cultural hero as a mythological image}

Myths about culture heroes are one of the powerful layers of oral folk art. In archaic myths, the culture hero is the personification of the power of the genus and becomes a propagandist of its ideology. He was respected on a par with the gods, because he often had a divine origin or was worshiped as a result of his activities. For the primitive community, the culture hero is the sacred ancestor of a tradition, rite, ritual that models the human beginning. In his activity he obtains, for the first time creates, finds or steals from the previous owner (supreme deity, spirit, etc.) various cultural objects and goods of civilization (fire, wild useful plants, tools, etc.), teaches people how to hunt, teaches skills in science, art, agriculture, crafts, norms of social life and sacred rituals, introduces a certain social organization, marriage rules, magic prescriptions, rituals and holidays.

For all cultures at the stage of primitive thinking culture heroes are the same, and their actions are aimed at cosmization of existence: the separation of earth and water, the emergence of modern terrain, celestial vaults and lights, the creation of wildlife and people, the 
organization of natural processes - change of day and night, season, the alternation of tides, the origin of various natural phenomena, etc. Thus, the culture hero performs a civilizing function, marking with his name a tradition, a ritual that is preserved from generation to generation. Often he carries out the activity in parallel worlds. It should be noted that movement and dynamics are extremely important for him. Almost all of his images are characterized by motives for search, travel, adventure and, in general, active movements in the cultural space (Hercules, Theseus, Perseus, etc.).

The term "culture hero" was first introduced by the German historian, sociologist, philologist K. Breysig, who used the German word "heilbringer" to denote it, which literally means "savior". In the interpretation of K. Breysig (Breysig, 1905), it was believed that the culture hero underwent an evolution from semi-zoomorphic ancestral spirits to anthropomorphic gods, who later became a figure of the supreme deity. The travels of a culture hero are attempts by people to realize various things and phenomena in nature, in particular, the alternation of day and night, the movement of celestial bodies, and others. However, the German anthropologist and ethnographer P. Ehrenreich (Ehrenreich, 1905) denied the interpretation of K. Breisig and believed that the culture hero is an emanation of a higher deity and has an astral nature.

It should be noted that the concept of "culture hero" from the beginning of the XX century was interpreted differently. Numerous researchers (A. Lang (A. Lang, 1901), W. Schmidt (Schmidt, 1933), E. Durkheim (Durkheim, 2018), S. Tokarev (Tokarev, 2008), H. Tegnaeus (Tegnaeus, 1950), Y. Meletinsky (Meletinsky, 1995)), find common features inherent in the image of a culture hero, namely his connection with the ancestors and creators-demiurges, partly with the "first people" (A. Lang), who are often the founders of the genus and introduce rites and cults. All actions, including the creation of the earth and people, are also associated with the culture hero. Researchers note that a culture hero could not be an ordinary person, adored by death, he could only be a hero who was attributed to the divine character and supernatural powers, which he possessed during his earthly life. The culture hero is associated with the higher deities and subordinates to them, but does not become sacred.

Thus, in different mythological systems, culture heroes do not necessarily have a sacred character and differ from "real" gods, because they can be associated with ancestral spirits, totems, prominent mythical, semi-legendary or real historical figures. However, an integral part of his work is a magical power without which the actions of a culture hero would be unthinkable. With the separation of the pantheon of higher gods, the culture hero can act as an assistant or arbiter between the worlds of gods and people, but at the same time conflicts between gods and culture heroes can arise.

It should be noted that a culture hero can be not only a person but also an animal with zooanthropomorphic features. He can also be a fighter against the natural phenomena of nature, which in turn are personified through the images of monsters and demons trying to destroy the already established order. Thus, etiological myths acquire the features of a heroic story, as the culture hero fights and guards the homes of people. Thus, the Africanist H. Baumann (Baumann, 1964) notes the teratomorphic (translated from the Greek "monster") and clownish aspects of the culture hero.

The American anthropologist P. Radin (Radin, 1999) emphasizes the primary independence of the culture hero and the supreme deity, but notes that gradually their features began to mix, the culture hero increasingly embodied the features of a higher deity and became the creator or transformer of elements of nature and culture.

Y. Meletinsky and W. Schmidt emphasize the mediation inherent in the culture hero, because he is the arbiter between the world of gods and the world of people. The German 
researcher emphasizes five types of culture hero: 1) a defender who frees people from the evil monster. He is an image of fantastic tales and epic poems; 2) creator of objects of culture and civilization, teacher; 3) the "great legislator"; 4) sage/prophet, he establishes ethical and religious forms, introduces ceremonies and holidays; 5) organizer and compiler of the world (Schmidt, 1933).

Extremely important in the field of mythopoetics are the studies of the Russian philologist, cultural historian Y. Meletinsky, who defines the general functions of a culture hero: 1) the creation of the world or its revival from Chaos; 2) the fight against the mythical monsters of Chaos, which are the carriers of the destructive elements of the mythical chronotope; 3 ) the creation of people; 4) introduction into the social world of culturally significant objects of the material plan and spiritual values; 5) demonstration of certain goals to be pursued in order to identify with the mythological hero, discovering new individual opportunities for personal development; 6) mediation between worlds in the mythological model of the world (Meletinsky, 1995:178). We will add another important aspect on which Y. Meletinsky emphasizes - the connection of the culture hero with the mythical time, because all his actions are "a metaphorical code by which the structure of the world, natural and social is formed" (Meletinsky, 1995:172).

According to culturologists A. Pelipenko and I. Yakovenko (Pelipenko, Yakovenko, 1998), the culture hero in his constant meaning, as a sacred improver of the world, teacher, inventor and winner of anti-cultural chaotic forces, was formed as a result of gradual separation from syncretic unity with the functions of demiurge. Another culturologist and historian, A. Gurevich, defines a culture hero as one of the central characters of ancient mythology, "who imparts to the team the knowledge and skills that are vital to the existence of society" (Gurevich, 2009:22).

It should be noted that the actions of a culture hero are not always aimed at improving human life, but always provoke historical change. Often the negative backup of a culture hero competes with his twin brother and at the same time can be endowed with comic and demonic traits, acting as a trickster. If a culture hero does not have a twin brother, he combines serious actions and clownish antics in his person. In etiological myths, the images of a culture hero and a trickster represent a single whole. Their separation was a later stage in the development of mythology.

The genesis of the culture hero took place in two directions: 1) God-Creator or messiah (as well as the ancestor) or 2) epic hero (for example, Ilya Muromets, Dobrynya, etc.). Some features of the culture hero can be found in the activities of the gods (Enki and Enlil in Sumerian, Odin in Scandinavian mythology, etc.), because they not only create the world, but also perform cultural acts. Thus, as researchers note (B. Ivanov, S. Tokarev, V. Toporov (Tokarev, 2008) etc.), in the process of transition from the cosmological and the divine to the historical and human, it is as if the last representative of the cosmological series is combined with the first representative of the historical. At the junction of these two series, a culture hero emerges, who completes the arrangement of space, but in its human dimension.

As already mentioned, in the process of culturogenesis, the culture hero took on the functions of a mediator, a mediator between the transcendent-sacralized creator and the world of profane reality. It should be noted that such mediation is dynamic and during evolution has created a plurality of mythological, folklore, literary images. Unlike the metaphysical creator-demiurge, who directly creates things and organizes them in the cosmic order, the culture hero usually improves, perfects and extracts things that already exist in existence. We can say that the culture hero as it were "translates a thing from an ideally eidetic to a utilitarian-pragmatic plan. On the other hand, the culture hero never completely merges with the profane world" (Pelipenko, Yakovenko, 1998:130). Thus, occupying an intermediate place between 
the creator-demiurge and ordinary people, the culture hero defines his "semi-sacred nature" (A. Pelipenko, I. Yakovenko) as a mediator.

Being in the position of a mediator, the culture hero combines features of restoration of the destroyed, reproduction of the lost, reconstruction of blurred and profaned sacred traditions, as well as features of innovative creativity, various discoveries and inventions. His motives and forms of activity are generally subject to the causal laws of reality, although they always contain elements of the heroic, superhuman and supernatural.

As culture developed, various types of cultural activities appeared, and accordingly the spheres of manifestation of the functions of a culture hero. In particular, the concept of culture hero is applied to the heroes of the epic, characters of history, art, outstanding personality, whose activities, in terms of prevailing morality, aesthetics and taste, are extremely positive. Such culture heroes can be heroic romantic personalities (according to T. Carlyle (Carlyle, 2008)), superman (according to F. Nietzsche, "Übermensch" (Nietzsche, 2007)), charismatic leader of the masses, wise dictator, universal genius, artist-prophet and creator of a new reality, values and world foundations.

\section{Poem / opera "Moscow-Petushki"}

V. Yerofeyev's poem "Moscow-Petushki" is a pseudo-biographical postmodernist composition written in 1969 and widely distributed in underground press. Officially in the USSR, the poem was published in shortened form in the issues of the magazine "Abstinence and Culture” № 12 (1988) and № 1-3 (1989) during the anti-alcohol propaganda of Mikhail Gorbachev. In this edition, the poem "Moscow-Petushki" had a large number of errors, bills, which distorted the basic meaning, which was invested in it by V. Yerofeyev. Only in 1989 was the composition published in full by Prometheus Publishing House.

The protagonist of the poem is the intellectual alcoholic Venichka Yerofeyev, who appears as the author's alter ego, because the author gives him his name, and thus he seems to accept all the sins, suffering, death, which he describes in the first person. There is a certain mystical connection between the author and the protagonist of the poem, because in the composition Venichka Yerofeyev dies from the fact that his throat is pierced with an awl, and in reality, $\mathrm{V}$. Yerofeyev died from throat cancer.

S. Lunov became acquainted with the poem "Moscow-Petushki" in 1990 after the death of the author of the poem. In the same year, the composer began to create a libretto, and in 1991 he began to write music. The composer got acquainted in more detail with the work of V. Yerofeyev in the form of a theatrical play, which took place in the "Mirror" theater. S. Lunov worked on the opera for 21 years (1991-2012), he considered it one of the most important in his creative work. The composer felt the urgency of the plot of the poem at the turn of the era, when the Soviet Union collapsed and new states began to be created (Motsar, 2016). The plot of the opera is based on the journey of the main character Venichka, which is a search for a lonely soul and its "thorny" path to Paradise.

In addition to the main literary source, the composer uses in the libretto and other texts of V. Yerofeyev, in particular, excerpts from the play "Walpurgis Night or Steps of the Commander", "Notes of a Psychopath", Notebooks of the writer. S. Lunov also makes text notes in the libretto (compared to V. Yerofeyev's poem - the composer does not include in the libretto an episode with the revolution in "Moscow-Petushki" and some stories of fellow travelers, etc.), because the genre basis of the opera "Moscow-Petushki" is a dramatic text, where the action that took place in the poem must be dominated by descriptiveness. However, this does not affect the perception of the poem, because it does not lose its main semantic core. 
It should be noted that both in the poem and in the opera, there are introduced mythologized infernal images, which emphasize the demonization of all events that take place and indicate the persecution of the protagonist's Fate. However, unlike the poem, the composer introduces into the libretto not only the images of the Sphinx and Satan, but also the generalized image of "Someone". Comparing these images in the text of the libretto and the poem itself, we would like to note that V. Yerofeyev divides the images of the Sphinx and Satan, while S. Lunov unites them, reduces them to a single general infernal sinister image, which at certain stages of the plot will appear behind different faces. The pervasive infernal line is emphasized by the reincarnation of this image(s) from Someone (which at first does not frighten at all) through the mysterious-mystical Sphinx to the fatally horrible image of Satan. In our opinion, there is a very interesting subconscious comparison with the Trinity (God the Father, God the Son and the Holy Spirit) in an inverted form. This is the other side of our world, its reverse side and, in a sense, desacralization, as well as the possibility of warning of an apocalyptic future that may come unexpectedly quickly. In the opera, this is reflected in the timbre of the low-key instruments, the use of a rhythm reminiscent of footsteps, and the use of texts from the requiem Mass - Dies irae, Tuba mirum, Benedictus, when Satan himself appears.

Among the differences between the libretto and the text of "Moscow-Petushki" there should also be mentioned the role of the Sphinx. Throughout the opera, it is a pervasive image that appears in the most crucial moments of the protagonist's life. That is why the Sphinx becomes one of the main factors in the development of the plot, its dynamization and reflection of the events that take place on the way and become almost key in the dramaturgy of the opera. In V. Yerofeyev's poem, the Sphinx will appear only during the culmination before the appearance of Satan, when the fate of Venichka is decided.

Comparing the text of V. Yerofeyev's poem "Moscow-Petushki" and the opera by $\mathrm{S}$. Lunov, we note that the composer begins the opera from the end of the text of the poem. That means, he uses the episode used at the end of the poem and puts it at the beginning of the opera as a prologue: "Once upon a time, in Lobnya, near the station, a man was killed by a train, and incomprehensibly killed..." (Erofeev, 2016:172). The listener of the opera does not yet know about the death of the main character at the end of the story. However, in this way, the composer from the very beginning anticipates the tragic outcome of the opera itself - the death of Venichka. According to O. Motsar, who in her dissertation research "Ideas of the theater of the absurd in the process of renewal of the musical theater of the last third of the XX - early XXI century" was the first to analyze S. Lunov's opera "Moscow-Petushki" in the context of esthetics of the absurd, gives the features of an epic story: "This technique removes the action, gives the features of an epic story: you feel the view from the side, the establishment of an initially defined time distance. The very name "Lobnya" gives an allusion to the place of the Skull (in Rus. "Lobnoe place"): on the one hand - Red Square in Moscow, on the other - Golgotha (which for Venichka becomes one and the same place, because it is on Red Square where Four crucify him). This technique allows you to draw a parallel with the genre of Passions" (Motsar, 2016:142-143).

Agreeing with the arguments of the Ukrainian musicologist, it should be added that the composer "removes" the tragic beginning, making it anti-tragic. From the very beginning of the opera there is a tendency towards parody, frivolity, play, destruction of traditional stable norms and values of human life, and he emphasizes the trickster beginning of the cultural hero in the opera. This approach of the composer speaks, on the one hand, about "the need to preserve the uniqueness of one's own life world regardless of the situation" (Kryvosheya, 2004:161), and on the other about a certain awareness of one's powerlessness before being. 


\section{The image of a cultural hero in S. Lunov's opera "Moscow-Petushki"}

The protagonist of S. Lunov's opera "Moscow-Petushki" Venichka Yerofeyev has the features of both a culture hero and a trickster, as he combines serious actions and clownish antics. This combination was inherent in the primary mythological origins, when the cultural hero and the trickster existed in syncretic unity.

As a culture hero, Venichka creates his own mythologized world, which is ideal for the main character and reflects the real one. Thus, in the opera "Moscow-Petushki" two worlds are opposed: the real, where the protagonist is a citizen of the USSR, a passenger of an electric train and the world, which the protagonist builds in his mind by means of constant self-reflection through alcohol intoxication, namely memories $=$ delusions $=$ hallucinations of Venichka (conversation with Angels, God, Someone, Sphinx, Satan, etc.). It should be noted that in his mythologized world Venichka appears in a lyrical, sublime context, namely as a man of high morals, an ideal lover, which is in stark contrast to his lower side in reality. This comparison of worlds indicates the dual nature and ambivalence of the protagonist, because in the world of consciousness of the hero Venichka appears as a cultural hero, and in the real world the protagonist has more traits of a trickster.

In the real world, Venichka confronts the realities of Soviet society and cannot take root in any of its social environments. He disagrees and tries to oppose Soviet ideology. However, Venichka never shows aggression in conflicts - neither in the situation with the restaurant, when he was thrown out into the street, nor in the scene with the Four Enthusiasts, who humiliated and criticized the main character for delicacy and high morals, nor in the final scene, when Venichka is attacked and killed. He tries to resolve the conflict through constructive dialogue. The motive of confrontation is also inherent in the culture hero, who is a fighter against the hardened foundations of the world.

Venichka clearly organizes his world of consciousness in the mythologized time and space, which is one of the features of a culture hero, because his actions are aimed at organizing life. Important for the protagonist of the opera are the places to which he attaches special mythological significance, namely: Kursk railway station, which symbolizes the beginning of the journey, as well as the life of the protagonist; Petushki - the image of an unattainable paradise, which Venichka cannot reach; traveling by electric train from Kursk railway station to Petushki is the life path of the protagonist, because the world of the electric train for Venichka is the whole universe, which is divided by clear boundaries-stops (names of pictures in the opera); the Kremlin is a myth of the Soviet state; Moscow, which appears as the embodiment of hell, because it is in Moscow that the most terrible events happen to the hero (including his death).

The main meaning of Venichka's existence in his mythologized space is his son, who appears in the opera / poem as a priceless treasure, is the personification of the hero himself. It should be noted how the author of the poem depicts the image of the protagonist's child - he uses the word "baby", although the child is three years old. In our understanding, the image of a "baby" is an image of a defenseless creature in need of care, love, and it is also an image of hope for the future. Perhaps in this way the protagonist relates himself to the baby, namely, to a person who also needs love and care, but under some circumstances did not get it.

Venichka Yerofeyev as a culture hero appears as a kind of teacher for fellow passengers on the train, Four enthusiasts from the dormitory. It should be mentioned that the protagonist is an intellectual who impresses us with his education and literacy. In his reflections he constantly relies on the facts of history and culture, on literary and biblical texts, prominent figures, and so 
on. Despite the "low" topics he discusses, in particular, the question of the unpredictability of howling, its main content and inner meaning are filled with deep philosophical meaning.

In the Third Interlude of the opera, S. Lunov introduces images of He and She, who represent the ideal mythological twins of Venichka and his beloved woman. Thus, there is an opposition of two polar pairs of real and ideal images, the real and the ideal world. The composer emphasizes this at the level of musical language. The interlude is built in a three-part form, the extreme fragments of which are full of lyricism, ario in nature, the music is sublime and light. Quite the opposite nature of the music in the middle: the vocal language of the characters becomes more expressive, declamatory and recitative intonations prevail, the language is quite chaotic, fast, confused, and the orchestra becomes more colorful and dynamic, which sounds contrasting to the beginning and end of the interlude and levels the thoughts of Venichka about ideal love.

It should be noted that the protagonist of the opera / poem is constantly on the move, which is also one of the characteristics of the cultural hero and trickster, which, as it was correctly mentioned by M. Lipovetsky (Lipovetsky, 2009), are almost always depicted as a "man of the road" (which is totally about the opera / poem "Moscow-Petushki"). For Venichka, such regular trips are the basis of his life. Violation of this movement, namely coming to the Red Square, would break the cycle and mean death for Venichka. Thus, in the life of the protagonist there is an "eternal return" (according to F. Nietzsche), which is for him not just an opportunity to repeat any phenomenon, not only a return to himself, but also the inability of Venichka to break out of life, because all this is a constant movement in a circle.

In the third picture of "Moscow-Serp i Molot" by S. Lunov's opera, the protagonist has a monologue/dialogue with the Lord God. In terms of music, there is a comparison of confused and pleading intonations, there are large ascending jumps, seconds (intonations of prayer/crying) of Venichka and the part of God that is recited. S. Lunyov used various sound effects - the voice of God sounds distant, and is constantly reflected in the echo. Thus, the effect of the Lord's presence is achieved not as a close interlocutor, but as one who is everywhere.

Venichka in the opera "Moscow-Petushki" appears as a twin of the main character of the musical composition - Jesus Christ, because according to the Russian literary critic E. Smirnova, "Venichka is Jesus Christ, who is in an earthly, profane, inverted world" (Smirnova, 1990:64). Such ambivalence makes it possible to turn a comedy into a tragedy, creates "unusual profane possibilities of a comedian" (A. Pelipenko, I. Yakovenko), so the language of opera / poem is characterized by semantic duality of words, music and image, in which the story of Venichka-writer, an intellectual of the protagonist of the poem, a servant of language is embodied in the story of a servant of alcohol, a marginal, who, on the one hand, destroys all conceivable and unthinkable canons of Soviet life, and on the other, creates the opportunity to be a "sacred profligate" (Pelipenko, Yakovenko, 1998).

Like the culture hero, Venichka has a feature of mediation, he is constantly on the border between the real and unreal world, namely the world of his painful consciousness. He is able to have a dialogue both with the characters of the real world - Waitress, Bouncer, Controller Semyonych, and with representatives of the afterlife: beings of higher order - Angels, God; infernal images - Someone, Sphinx, Satan; images that are an expression of certain features that are necessary for the hero's self-identification - Venichka's companions: Vusaty, Mitrych, Onuchok (Grandson); images of their delusions - Duchess, Old, Grandmother and others. Thanks to Venichka's trickster features, in the poem/opera by Yerofeyev/Lunyov they are turned over, accents in permanent axiological models are rearranged, the process of alienation of consciousness from certain constant values is softened, thus consciousness is 
freed from existential experience of "true blessings". This fact is extremely important for us, because passing through all possible semantic cultural values, Venichka Yerofeyev does not linger on anything seriously, he is in a constant dynamic formation, provoking the search for new meanings in life.

\section{Conclusions}

The characteristics of the image of a culture hero, his role in archaic mythology and modern musical art are presented. It is noted that the following functions are characteristic of a culture hero: 1) creative, because he creates/ revives the world from the initial Chaos, creates people; 2) protective - he protects people from mythical monsters; 3 ) cultural and organizational - he teaches people the art and the introduction of spiritual values, the organization of socio-cultural relations within society; 4) didactic - he teaches people different crafts, organizes their lives, promotes personal development, because often a cultural hero is an example to follow; 5) mediation - mediation between worlds. It is determined that in the modern world the culture hero is present in almost all spheres of social activity, he embodies and promotes the dominant values and moral attitudes to society.

It was studied that the activities of a culture hero are not always aimed at exceptionally positive changes in human society, which makes him close to the image of a trickster, however, it is what provokes historical change. The combination of these images is inherent in primitive mythology, when the culture hero and the trickster existed syncretically. Therefore, the image of a culture hero reveals an ambivalent and dualistic nature, as it combines both serious activities aimed at cultural creation and clownish behavior.

It is noted that ambivalence in S. Lunov's opera is manifested at different levels. This is a comparison of the characters of Venichka and Ruda and their ideal twins (He and She), what creates a relationship of two poles - sublime and serious (He and She) and low and clownish (Venichka and Ruda); comparison of mythologized and real worlds (in the opera Venichka appears as a declined twin of Jesus Christ). In addition, Venichka Yerofeyev as a culture hero acts as a mediator between the real world and the unreal (the world of his consciousness); he creatively transforms and organizes reality (creates its own mythologized world, which is clearly organized in space and time); he is constantly on the move (regular trips of the protagonist to the Petushki, symbolizing his life's journey to Paradise and the obsession of the movement, because his travels are constantly repeated); he tries to oppose the dominant rigid moral foundations of Soviet ideology (resolves conflicts through constructive dialogue), appears as a teacher who promotes his own worldview. The mythopoetics of the image of the main character in S. Lunov's opera "Moscow-Petushki" considered in the article can be used for further explorations and researches.

\section{References}

Baumann, H. (1964). Schöpfung und Urzeit des Menschen im Mythus der afrikanischen Völker. Berlin: Reimer.

Bentia, Yu.V. (2020). Kulturnyi heroi sentymentalizmu v zhanrovo-stylovii kartyni svitu [Culture hero of sentimentalism in the genre-style picture of the world]. Candidate's thesis. Kyiv [in Ukrainian].

Breysig, K. (1905). Die Entstehung des Gottesgedankes und der Heilbringer. Berlin: Georg Bondi. 
Durkheim, E. \& Kurakin, D.Yu. (Eds.). (2018). Elementarnye formy religioznoj zhizni : totemicheskaya sistema $v$ Avstralii [Elementary Forms of Religious Life: The Totemic System in Australia]. (V.V. Zemskova, Trans.). Moscow: Elementarnye formy [in Russian].

Ehrenreich, P. (1905). Die Mythen und Legenden der Sudamerikanischen Urvölker und ihre Beziehungen zu denen Nordamerikas und der alten Welt. Berlin: Asher \& Co.

Eliade, M. (2010). Aspekty mifa [Aspects of the myth]. (V.P. Bolshakov, Trans.). (4th ed.). Moscow: Akademicheskij Proekt [in Russian].

Erofeyev, V. (2016). Moskva-Petushki: poema [Moscow-Petushki: poem]. St. Petersburg: Azbuka-Attikus [in Russian].

Genis, A. (1997). Beseda pyataya. Blagaya vest. Venedikt Erofeev [Fifth Conversation. Good news. Venedikt Erofeev]. kirovsk.narod.ru. Retrieved from http://kirovsk.narod.ru/culture/ludi/ erofeev/articles/genis.htm. [in Russian]

Gurevich, A.Ya. (2009). Individ i socium na srednevekovom Zapade [The individual and society in the medieval West]. Ryazan: Aleksandriya [in Russian].

Hrytsenko, O. (Eds.). (1999). Heroi ta znamenytosti v ukrainskii kulturi [Heroes and celebrities in Ukrainian culture]. Kyiv: UTsKD [in Ukrainian].

Carlyle, T. (2008). Geroi, pochitanie geroev i geroicheskoe v istorii [Heroes, hero worship and the heroic in history]. Moscow: Eksmo [in Russian].

Kryvosheya, T.O. (2004). Antytrahediine v suchasnomu filosofsko-estetychnomu dyskursi [Antitragic in modern philosophical and aesthetic discourse]. Candidate's thesis. Kyiv [in Ukrainian]. Lang, A. (1901). Myth, Ritual and Religion. New York and Bombay: Longmans \& Co.

Lashchenko, S.K. (2004). Venedikt Erofeev. Poema "Moskva-Petushki": opyt muzykovedcheskogo issledovaniya [Venedikt Erofeev. Poem "Moskva - Petushki": the experience of musicological research]. Mir iskusstv. Almanah. - The world of arts. Almanac. (Issue 5), (pp. 258-285). St. Petersburg: Aletejya [in Russian].

Lévi-Strauss, C. (2001). Strukturnaya antropologiya [Structural anthropology]. (V.V. Ivanov, Trans.). Moscow: Izd-vo EKSMO-Press. [in Russian].

Lipovetsky, M. (2009). Trikster $i$ "zakrytoe" obshestvo [The Trickster and the Closed Society]. magazines.gorky.media. Retrieved from https://magazines.gorky.media/nlo/2009/6/trikster-i-zakrytoe-obshhestvo.html [in Russian].

Lipovetsky, M. (1997). Russkij postmodernizm. (Ocherki istoricheskoj poetiki): Monografiya [Russian postmodernism. (Essays on Historical Poetics): Monograph]. Yekaterinburg: Ural. gos. ped. un-t. [in Russian].

Meletinsky, Y.M. (1995). Poetika mifa [Poetics of myth]. (2nded.). Moscow: Izd-vo "Vostochnaya literatura" RAN, "Yazyki russkoj kultury". [in Russian].

Motsar, O.V (2016). Idei teatru absurdu u protsessakh onovlennia muzychnoho teatru ostannoi tretyny XX-pochatku XXI stolittia [Ideas of the theater of the absurd in the process of updating the musical theater of the last third of the XX-early XXI century]. Candidate's thesis. Kyiv [in Ukrainian].

Motsar, O.V. (2014). Opera Sviatoslava Lunova "Moskva - Petushki": interpretatsiia literaturnoho pershodzherela [Svyatoslav Lunyov's opera "Moskva - Petushki": interpretation of the literary source]. Ukrainske muzykoznavstvo : nauk.-metod. zb. - Ukrainian musicology: scientific method. digest. (Issue 40.). (pp. 25-34). Kyiv [in Ukrainian].

Nietzsche, F. (2007). Tak govoril Zaratustra [Thus Spoke Zarathustra]. Moscow: Martin [in Russian].

Pelipenko, A.A., Yakovenko, I.G. (1998). Kultura kak sistema [Culture as a system]. Moscow: Izd-vo "Yazyki russkoj kultury" [in Russian]. 
Radin, P. (1999). Trikster: issledovanie mifov severoamerikanskih indejcev s komment. K. G. Yunga i K. K. Kereni [The Trickster: A Study of the Myths of the North American Indians with a Commentary. K.G. Jung and K.K. Kerenyi]. St. Petersburg: Evraziya [in Russian].

Schmidt, W. (1933). High Gods in North America. New York: Oxford University Press.

Smirnova, E.A. (1990). Venedikt Erofeev glazami gogoleveda [Venedikt Erofeev through the eyes of a gogol scholar]. Russkaya literature - Russian literature, 3, 58-66. Moscow [in Russian].

Tegnaeus, H. (1950). Le héros civilisateur. Contribution à l'Étude Ethnologique de la Religion et de la Sociologie Africaines. Stockholm: Studia Ethnographica Upsaliensia II.

Tokarev, S. (Eds.). (2008). Mify narodov mira [Myths of the World's Nations]. Moscow [in Russian].

Vasina, N. (2009). Tema kulturno-istoricheskoj pamyati v fortepiannom cikle S. Luneva "Mardongi" [The theme of cultural and historicalmemory in S. Lunev's piano cycle "Mardongi”]. Kyivske muzykoznavstvo - Kyiv musicology (Issue 29.). (pp. 47-55). Kyiv [in Ukrainian].

Jung, C. (1996). Dusha i mif: shest arhetipov. [Soul and myth: six archetypes]. Kyiv: Gos. bibl. Ukrainy dlya yunoshestva [in Russian]. 